\title{
36. A GEOCHEMICAL STUDY OF 17 SELECTED SAMPLES FROM BASEMENT CORES RECOVERED AT SITES 447, 448, 449, 450, AND 451, DEEP SEA DRILLING PROJECT LEG 59
}

\author{
D. A. Wood, ${ }^{1}$ D. P. Mattey, ${ }^{1}$ J. L. Joron, ${ }^{2}$ N. G. Marsh, ${ }^{1}$ J. Tarney, ${ }^{1}$ and M. Treuil ${ }^{2}$
}

\section{INTRODUCTION}

Deep Sea Drilling Project Legs 59 and 60 drilled 15 sites along an east-west transect at $18^{\circ} \mathrm{N}$ from the West Philippine Basin to the Mariana Trench (Fig. 1) in order to study the nature and genesis of the back-arc, marginal basins and the remnant and active arcs of the region. Leg 59 drilled at five sites at the western end of the traverse: Site 447 in the West Philippine Basin; Site 448 on the Palau-Kyushu Ridge; Sites 449 and 450 in the Parece Vela Basin; and Site 451 on the West Mariana Ridge. Penetration into basaltic basement of these sites was 183.5 meters at 447 ( 8 basalt flows); 623 meters at 448 ( 46 basalt flows, sills, and dikes and volcaniclastic units); 40.5 meters at 449 ( 2 basalt flows); 7 meters at 450 ( 1 basalt intrusion); and 4 meters of basalt breccia at 451 overlain by 861 meters of volcaniclastic sedimentary rocks.

The petrology, mineralogy, and geochemistry of these cores have been described by Mattey et al. (this volume). They have distinguished the main igneous units recovered on the basis of X-ray fluorescence (XRF), whole rock geochemical data, microprobe data for minerals and glasses, and petrography. From these data we have chosen 17 samples which are representative of the main compositional units and subjected them to epithermal neutron activation analysis (Chayla et al., 1973; Jaffrezic et al., in press) to obtain high precision data for a number of trace elements (viz. Sc, $\mathrm{Co}, \mathrm{Cs}, \mathrm{La}, \mathrm{Ce}, \mathrm{Eu}, \mathrm{Tb}, \mathrm{Hf}, \mathrm{Ta}, \mathrm{Th}$, and $\mathrm{U}$ ) which could not be obtained by XRF. The core intervals of the 17 samples are given in Table 1 together with a summary of the nature and size of the compositional units from which they are taken. Major and trace element analyses of the samples are given in Table 2.

One aim of this study has been to compare the composition of these rocks with those erupted in other tectonic environments to elucidate the chemical characteristics of basaltic crust formed at active plate margins which consist of a series of remnant island arcs and interarc basins. Data for mid-ocean ridge basalts and the lava series of Japan have been particularly useful to us in this respect.

\footnotetext{
${ }^{1}$ Department of Geological Sciences, University of Birmingham, Birmingham, B15 2TT, England. (Dr. Tarney's present address: Department of Geology, University of Leicester, Leicester, United Kingdom.)

2 Laboratoire de géochimie comparée et systématique, UER des Sciences de la Terre et Institut de Physique du Globe, Université Pierre et Marie Curie, 75230. Paris, France, and Group des Sciences de la Terre, Laboratoire Pierre Sue, CNRS Centre d'Études Nucléaires de Saclay, Gif-sur-Yvette, France.
}

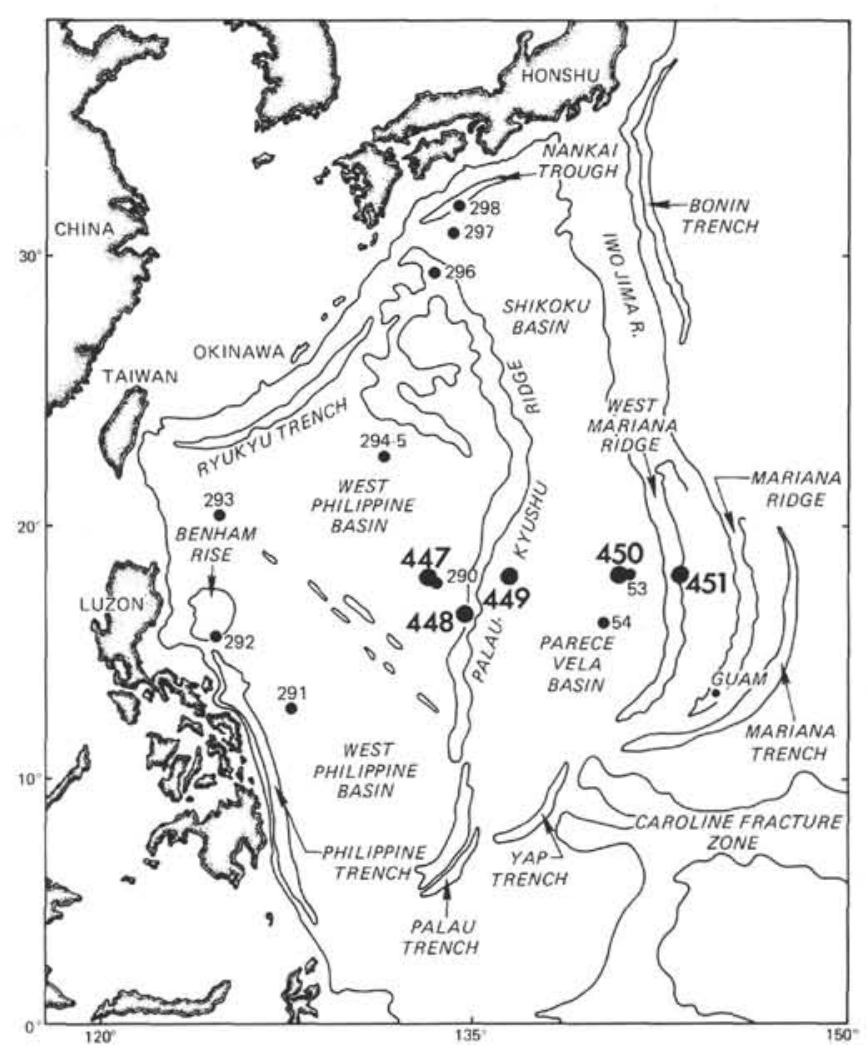

Figure 1. Location of drill sites for DSDP Leg 59.

\section{THE MAIN GEOCHEMICAL CHARACTERISTICS OF THE SITES}

The basement rocks recovered during Leg 59 can be divided into two main compositional groups, on the basis of major and trace element chemistry (and petrography), which correspond to the basin $(447,449$, and 450$)$ and ridge (448 and 451) sites. The basin sites are low alkali tholeiites with high $\mathrm{Mg}$ numbers $(\mathrm{Mg} /[\mathrm{Mg}$ $+\mathrm{Fe}^{2+}$ ] from 0.65 to 0.73 ) and $\mathrm{CaO}$ contents but low abundances of the more hygromogmatophile (HYG) or incompatible trace elements (e.g., Ba, Th, Ta, and La). The ridge sites also consist of tholeiitic rocks but have lower $\mathrm{Mg}$ numbers $(0.40-0.59)$ and significantly higher abundances of $\mathrm{Sr}$ and the alkali elements than the basin sites. The rocks from the basin sites show clear geochemical affinities with normal (N-type) mid-ocean ridge basalts, whereas the rocks from the ridge site are similar to those associated with active plate margins. 
Table 1. Leg 59 samples used in this study, with a summary of the main chemical and petrographic units.

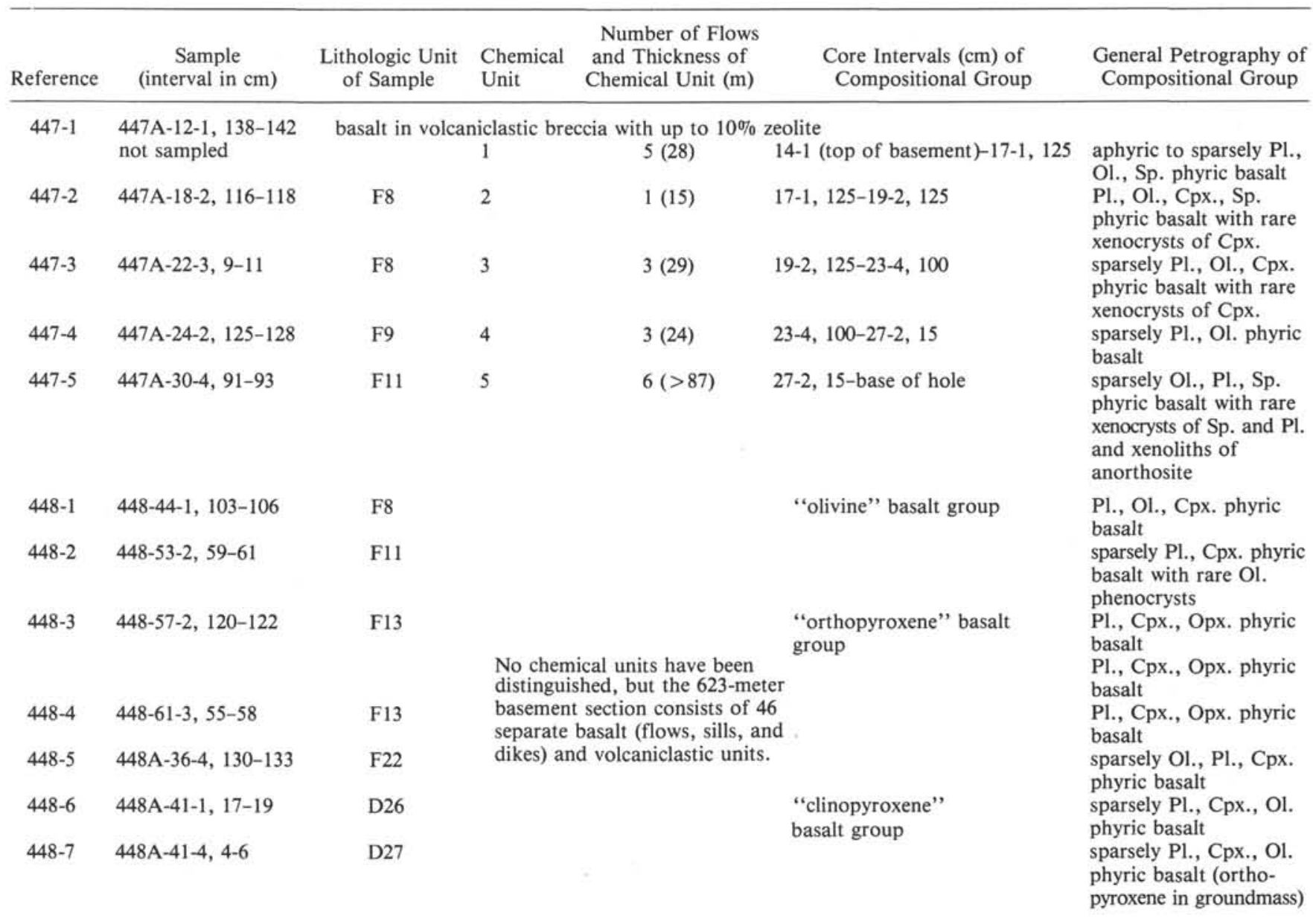

\begin{tabular}{|c|c|c|c|c|}
\hline 449 & $449-15-2,11-13$ & no units distinguished & $\begin{array}{l}\text { ( } 40 \text { meters of pillow basalt penetrated, only } \\
7 \text { meters recovered) }\end{array}$ & $\begin{array}{l}\text { sparsely Pl., Ol., Cpx., } \\
\text { Sp. phyric basalt }\end{array}$ \\
\hline 450 & $450-36-3,7-9$ & no units distinguished & $\begin{array}{l}\text { (7 meters of pillow basalt penetrated, only } \\
2 \text { meters recovered) }\end{array}$ & Pl., Cpx. phyric basalt \\
\hline $451-1$ & $451-45-1,29-32$ & & & Pl. phyric basalt \\
\hline $451-2$ & $451-46-1,24-30$ & no units distinguished & basalt and andesite clasts in a volcaniclastic breccia & Pl., Ol. phyric basalt \\
\hline $451-3$ & $451-59-1,54-59$ & & & $\begin{array}{l}\text { Cpx. and Opx. phyric } \\
\text { andesite }\end{array}$ \\
\hline
\end{tabular}

Note: $\mathrm{F}=$ flow unit, $\mathrm{D}=$ dike unit, $\mathrm{C}=$ chemical unit (see Mattey et al., this volume); $\mathrm{Pl} .=$ plagioclase, $\mathrm{Ol} .=$ olivine, $\mathrm{Sp} .=$ sphene, Cpx. = clinopyroxene, Opx. = orthopyroxene.

Figure 2 is an AFM diagram on which the Leg 59 rocks have been plotted, together with rocks from the arc tholeiite and calc-alkalic series of Japan (Wood et al., in press). It indicates that the ridge sites are more Fe-rich than the basin sites but also enriched in alkalis relative to $\mathrm{Fe}$ than is the arc tholeiite series of Japan. The higher alkali content of the ridge sites relative to the arc tholeiites of Japan is apparent on an alkali-silica plot (Fig. 3) and is due to the systematically lower $\mathrm{Na}_{2} \mathrm{O}$ contents of the Japanese arc tholeiite series. In both Figure 2 and Figure 3 rocks from the ridge sites plot in similar positions to the Japanese calc-alkali series.
There are significant geochemical differences between the rocks from the two ridge sites (Table 2): Site 451 rocks have higher abundances of $\mathrm{Sr}, \mathrm{Ba}$, and the alkali elements and higher ratios of more HYG (hygromagmatophile)/less HYG elements (e.g., Th/Hf, La/Tb, etc.) but with lower abundances of $\mathrm{Fe}$ and $\mathrm{TiO}_{2}$ than Site 448 . Core $451-3$ is a two-pyroxene andesite. The Site 451 rocks therefore have more of the chemical characteristics of a calc-alkalic series than those of Site 448 . This indicates that the West Mariana Ridge represents a more evolved island arc than does the Palau-Kyushu Ridge. 
Table 2. Major and trace element analyses of 17 selected samples from the basement cores of DSDP Leg 59.

\begin{tabular}{|c|c|c|c|c|c|c|c|c|c|c|c|c|c|c|c|c|c|c|}
\hline \multirow[b]{2}{*}{ Component $t^{\mathrm{a}}$} & \multicolumn{5}{|c|}{ West Philippine Basin } & \multicolumn{7}{|c|}{ Palau-Kyushu Ridge } & \multicolumn{2}{|c|}{$\begin{array}{l}\text { Parece-Vela } \\
\text { Basin }\end{array}$} & \multicolumn{3}{|c|}{ West Mariana Ridge } & \multirow{2}{*}{$\begin{array}{l}\text { Analytical } \\
\text { Method }\end{array}$} \\
\hline & 447.1 & 447.2 & $447-3$ & 447.4 & $447-5$ & $448-1$ & $448-2$ & 448-3 & $448-4$ & $448-5$ & $449-6$ & $447-7$ & 449 & 450 & $451-1$ & $451-2$ & $45 t-3$ & \\
\hline $\mathrm{SiO}_{2}$ & 49.0 & 50.7 & 50.6 & 47.2 & 49.4 & 49.6 & 49.2 & 48.9 & 50.2 & 50.6 & 49.7 & 50.5 & 49.4 & 50.0 & 48.1 & 50.6 & 57.3 & (XRF) \\
\hline $\mathrm{TiO}_{2}$ & 0.85 & 1.41 & 1.13 & 0.83 & 0.89 & 1.54 & 1.15 & 0.81 & 1.12 & 0.95 & 1.25 & 1.43 & 0.99 & 1.43 & 0.59 & 0.77 & 0.65 & (XRF) \\
\hline $\mathrm{Al}_{2} \mathrm{O}_{3}$ & 15.7 & 14.6 & 14.5 & 15.7 & 15.2 & 14.0 & 14.7 & 17.1 & 15.0 & 13.5 & 13.6 & 13.1 & 14.4 & 15.3 & 19.8 & 15.9 & 17.7 & (XRF) \\
\hline $\mathrm{Fe}_{2} \mathrm{O}_{3}$ & 1.17 & 1.24 & 1.22 & 1.16 & 1.16 & 1.87 & 1.62 & 1.40 & 1.47 & 1.54 & 1.61 & 1.70 & 1.25 & 1.09 & 1.20 & 1.34 & 0.86 & (XRF) \\
\hline $\mathrm{FeO}$ & 7.72 & 8.20 & 8.08 & 7.67 & 7.35 & 12.32 & 10.66 & 9.21 & 9.69 & 10.17 & 10.65 & 11.21 & 8.24 & 7.22 & 7.91 & 8.81 & 5.69 & \\
\hline $\mathrm{MnO}$ & 0.16 & 0.15 & 0.18 & 0.16 & 0.16 & 0.23 & 0.20 & 0.22 & 0.15 & 0.26 & 0.21 & 0.22 & 0.14 & 0.17 & 0.18 & 0.17 & 0.15 & (XRF) \\
\hline $\mathrm{MgO}$ & 8.37 & 8.24 & 9.13 & 11.61 & 9.23 & 4.63 & 5.19 & 5.37 & 6.30 & 8.18 & 6.70 & 7.26 & 9.14 & 7.58 & 4.86 & 6.70 & 3.03 & (XRF) \\
\hline $\mathrm{CaO}$ & 12.93 & 12.01 & 12.07 & 11.67 & 12.66 & 9.54 & 10.23 & 10.56 & 8.84 & 10.33 & 9.15 & 8.94 & 12.25 & 13.08 & 12.60 & 9.58 & 8.60 & (XRF) \\
\hline $\mathrm{Na}_{2} \mathrm{O}$ & 2.69 & 2.96 & 2.83 & 2.82 & 2.79 & 3.09 & 3.00 & 2.72 & 3.57 & 2.97 & 3.14 & 3.39 & 3.16 & 3.22 & 2.55 & 3.04 & 3.65 & (NAA) \\
\hline $\mathrm{K}_{2} \mathrm{O}$ & 0.39 & 0.39 & 0.06 & 0.05 & 0.48 & 0.57 & 0.47 & 0.56 & 1.41 & 0.16 & 1.28 & 0.50 & 0.46 & 0.23 & 0.26 & 0.62 & 2.13 & (XRF) \\
\hline $\mathrm{P}_{2} \mathrm{O}_{5}$ & 0.06 & 0.10 & 0.08 & 0.05 & 0.07 & 0.19 & 0.12 & 0.03 & 0.13 & 0.08 & 0.17 & 0.12 & 0.08 & 0.11 & 0.10 & 0.23 & 0.14 & (XRF) \\
\hline $\mathrm{H}_{2} \mathrm{O}^{+}+$ & n.d. & n.d. & n.d. & n.d. & n.d. & n.d. & n.d. & n.d. & n.d. & n.d. & n.d. & n.d. & n.d. & n.d. & n.d. & n.d. & n.d. & \\
\hline Total & 99.03 & 100.01 & 99.88 & 98.92 & 99.69 & 97.59 & 96.54 & 96.88 & 97.88 & 98.74 & 97.46 & 98.37 & 99.61 & 99.42 & 98.15 & 97.76 & 99.90 & \\
\hline Total $\mathrm{Fe}$ as $\mathrm{FeO}$ & 8.77 & 9.32 & 9.18 & 8.71 & 8.39 & 14.00 & 12.12 & 10.47 & 11.01 & 11.56 & 12.10 & 12,74 & 9.36 & 8.20 & 8.99 & 10.02 & 6.36 & \\
\hline $\mathrm{Mg} /\left(\mathrm{Mg}_{\mathrm{g}}+\mathrm{Fe}^{2+}\right)$ & 0.658 & 0.641 & 0.668 & 0.729 & 0.691 & 0.400 & 0.464 & 0.536 & 0.509 & 0.588 & 0.528 & 0.535 & 0.663 & 0.651 & 0.522 & 0.574 & 0.486 & \\
\hline $\mathrm{Se}$ & 34.7 & 42.1 & 37.7 & 32.4 & 35.8 & 47.4 & 43.8 & 36.8 & 37.2 & 35.8 & 38.9 & 40.9 & 37.4 & 35.2 & 26.5 & 29.5 & 28.0 & (NAA) \\
\hline $\mathrm{Cr}$ & 332 & 199 & 257 & 265 & 340 & 92 & 91 & 67 & 79 & 320 & 78 & 74 & 205 & 256 & 54 & 71 & 43 & (NAA) \\
\hline Co & 40.9 & 55.6 & 49.3 & 47.0 & 51.0 & 39.4 & 39.5 & 37.5 & 36.9 & 46.7 & 37.8 & 51.4 & 39.5 & 49.9 & 31.4 & 31.9 & 18.6 & (NAA) \\
\hline $\mathrm{Ni}$ & 117 & 154 & 143 & 197 & 146 & 12 & 19 & 15 & 21 & 107 & 17 & 15 & 103 & 111 & 5 & 11 & 6 & (NAA) \\
\hline $\mathrm{Zn}$ & 71 & 82 & 69 & 53 & 62 & 117 & 92 & 75 & 83 & 118 & 99 & 113 & 63 & 71 & 68 & 66 & 68 & (XRF) \\
\hline Ga & 18 & 18 & 17 & 15 & 18 & 19 & 21 & 21 & 19 & 21 & 20 & 18 & 16 & 18 & 21 & 20 & 21 & (XRF) \\
\hline $\mathrm{Rb}$ & 5.2 & 4.7 & - & 2.3 & 4.2 & 5.2 & 4.5 & 4.9 & 12.6 & 2.1 & 12.5 & 3.5 & 4.7 & 2.4 & 2.3 & 6.8 & 39.4 & (NAA) \\
\hline $\mathrm{Sr}$ & 79 & 85 & 69 & 107 & 87 & 160 & 181 & 186 & 172 & 157 & 157 & 207 & 158 & 134 & 495 & 533 & 520 & (XRF) \\
\hline Y & 22 & 35 & 26 & 20 & 21 & 29 & 23 & 17 & 29 & 27 & 25 & 28 & 24 & 31 & 13 & 22 & 25 & (XRF) \\
\hline $\mathrm{Zr}$ & 43 & 68 & 51 & 53 & 48 & 47 & so & 45 & 74 & 40 & 39 & 60 & 61 & 89 & 31 & 66 & 83 & (XRF) \\
\hline Cs & 0.20 & 0.11 & 0.03 & 0.05 & 0.13 & 0.13 & 0.06 & 0.05 & 0.15 & 0.02 & 0.14 & 0.05 & 0.37 & 0.07 & 0.13 & 0.30 & 0.41 & (NAA) \\
\hline $\mathrm{Ba}$ & 6 & 7 & 10 & 11 & 10 & 22 & 41 & 23 & 41 & 14 & 14 & 26 & 20 & 13 & 18 & 188 & 467 & (NAA) \\
\hline $\mathrm{La}$ & 1.8 & 2.2 & 1.4 & 1.6 & 2.2 & 2.4 & 2.7 & 2.4 & 3.5 & 1.7 & 1.8 & 3.3 & 2.9 & 3.1 & 2.8 & 8.7 & 12.6 & (NAA) \\
\hline $\mathrm{Ce}$ & 5.0 & 6.4 & 5.3 & 5.2 & 5.3 & 4.5 & 4.0 & 5.6 & 6.0 & 4.1 & 4.5 & 5.9 & 7.2 & 7.7 & 4.2 & 17,3 & 21.4 & (NAA) \\
\hline Eu & 0.74 & 1.22 & 0.83 & 0.76 & 0.79 & 1.04 & 0.77 & 0.79 & 0.98 & 0.74 & 0.94 & 1.08 & 0.92 & 1.15 & 0.53 & 0.89 & 1.09 & (NAA) \\
\hline $\mathrm{Tb}$ & 0.48 & 0.81 & 0.63 & 0.45 & 0.52 & 0.73 & 0.52 & 0.38 & 0.62 & 0.45 & 0.51 & 0.66 & 0.49 & 0.69 & 0.29 & 0.52 & 0.56 & (NAA) \\
\hline $\mathrm{Hf}$ & 1.17 & 2.18 & 1.62 & 1.43 & 1.35 & 1.76 & 1.64 & 1.44 & 2.17 & 1.32 & 1.34 & 2.00 & 1.49 & 2.25 & 0.70 & 1.82 & 2.36 & (NAA) \\
\hline Ta & 0.06 & 0.12 & 0.07 & 0.05 & 0.16 & 0.03 & 0.04 & 0.04 & 0.05 & 0.02 & 0.01 & 0.04 & 0.18 & 0.15 & 0.02 & 0.70 & 0.10 & (NAA) \\
\hline Th & 0.07 & 0.15 & 0.08 & 0.10 & 0.21 & 0.23 & 0.30 & 0.41 & 0.35 & 0.25 & 0.16 & 0.34 & 0.27 & 0.15 & 0.38 & 1.56 & 2.30 & (NAA) \\
\hline U & 0.06 & 0.57 & - & - & - & 0.11 & - & - & 0.19 & 0.07 & 0.23 & 0.18 & 0.17 & 0.10 & 0.16 & 0.22 & 0.88 & (NAA) \\
\hline
\end{tabular}

Note: $\mathrm{XRF}=\mathrm{X}$-ray fluorescence, $\mathrm{NAA}=$ neutron activation analysis.

a Major element oxides in weight percent, trace elements in parts per million.

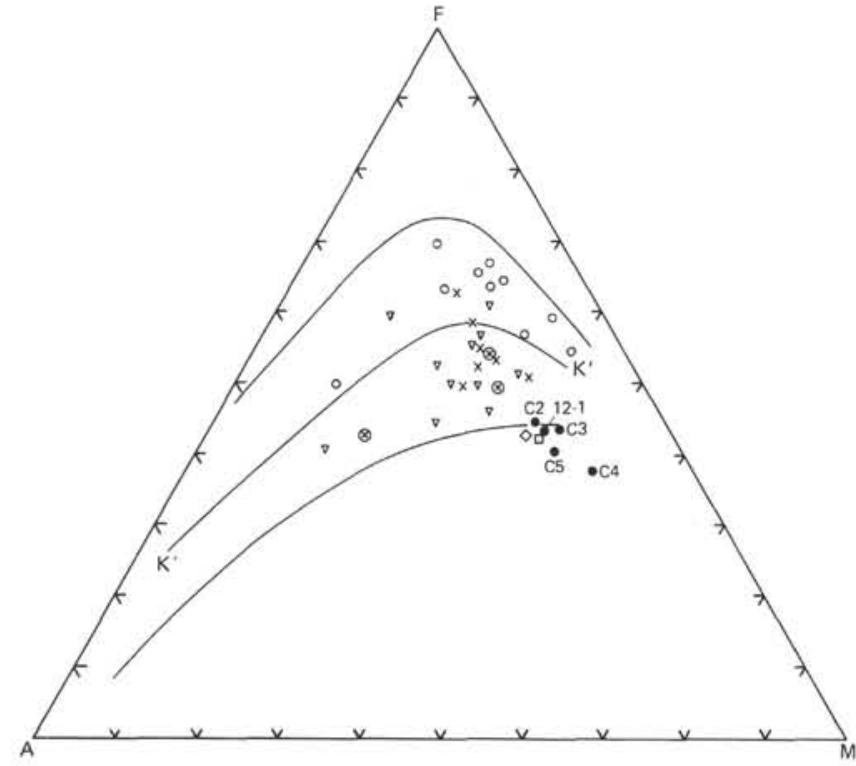

Figure 2. $\mathrm{MgO}-\mathrm{FeO}-\mathrm{Na}_{2} \mathrm{O}+\mathrm{K}_{2} \mathrm{O}$ triangular $\mathrm{AFM}$ diagram for DSDP Leg 59 basement samples and lavas from the calc-alkali (inverted triangle) and arc tholeiite (open circle) series of Japan (from Wood et al., 1980). The curved lines represent the general limits of Japanese lavas (Kuno, 1968), with the pigeonitic (arc tholeiite) series plotting above line $\mathrm{K}^{\prime}-\mathrm{K}^{\prime}$ and the hypersthenic (calc-alkalic) series plotting below it. (Site 447-filled circle, Site 448-cross, Site 449-open square, Site 450-open diamond, Site 451-cross in circle.)

\section{HYG Element Discrimination Diagrams}

Wood, Joron, and Treuil (1979) have recently shown that the relative abundances of the elements $\mathrm{Th}, \mathrm{La}, \mathrm{Ta}$, and $\mathrm{Hf}$ can be used to distinguish between volcanic series erupted in different tectonic environments. Nor-

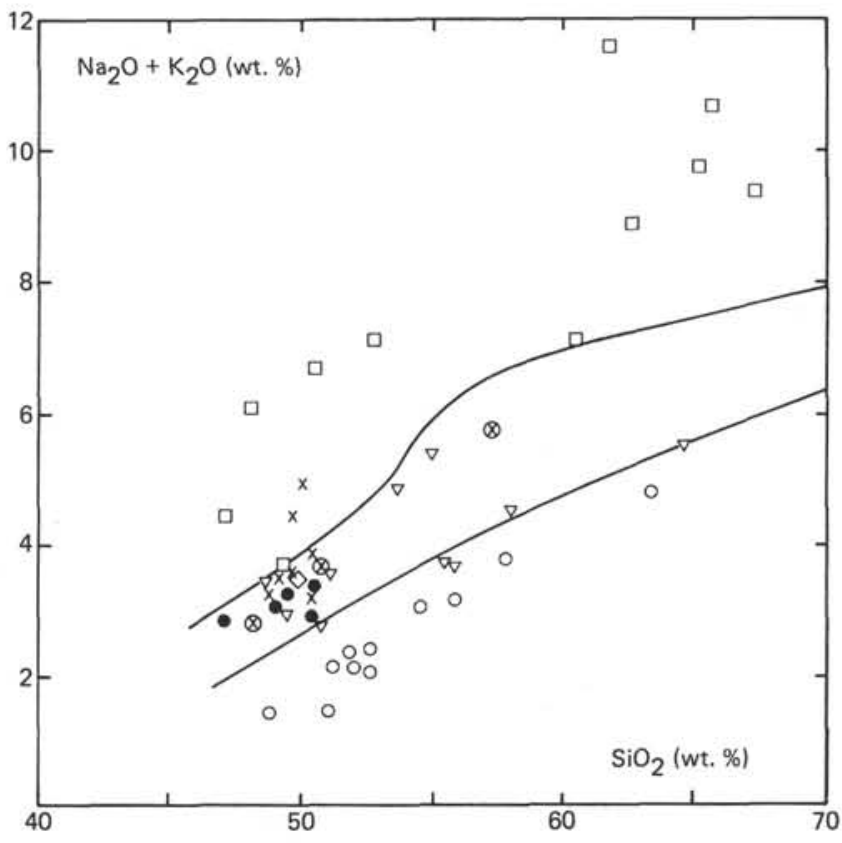

Figure 3. Alkali-silica diagram for DSDP Leg 59 basement samples and lavas from the calc-alkali, arc tholeiite, and alkalic series of Japan (from Wood et al., in press). The curved line represent the general limits of the high alumina basalt series of Japan (Kuno, 1968). (Symbols same as for Fig. 2.)

mal N-type MORB mid-ocean ridge basalts and E-type MORB (enriched in the more HYG elements and erupted at segments of mid-ocean ridges with positive residual heat flow, gravity, and depth anomalies relative to N-type MORB) can also be distinguished using these 
elements. The Leg 59 rocks have been plotted in Figures 4,5 , and 6 for comparison with well-studied volcanic series from other environments.

Figure 4 is a log-log plot of Th (more HYG element) versus Hf (less HYG element) and shows the progressive increase in $\mathrm{Th} / \mathrm{Hf}$ ratio from the basin sites to Site 448 (Palau-Kyushu Ridge) to Site 451 (West Mariana Ridge). Most of the samples from the basin sites (except for those from Chemical Unit 5, Sites 449 and 477, which show secondary enrichment of $\mathrm{Th}$-see the following) plot close to the field of N-type MORB, with $\mathrm{Hf} / \mathrm{Th}$ ratios greater than 12.5 . The Site 448 rocks plot close to the field of the Japanese arc tholeiites and the Site 451 rocks plot close to the field of the Japanese calc-alkalic series.

Figure 5 is a log-log plot of La (more HYG element) versus Ta (more HYG element). These two elements are thought to have very similar bulk partition coefficients between partial melts and a mantle residue consisting of major mineral phases-olivine, orthopyroxene, clinopyroxene, \pm garnet, and \pm plagioclase-(Joron et al., 1978; Wood, Varet, et al., 1979). In order to fractionate $\mathrm{La}$ and $\mathrm{Ta}$ from each other by magmatic processes it is necessary to involve minor phases-Ta (similar arguments apply to $\mathrm{Nb}$ ) is strongly partitioned into titanium mineral phases (e.g., ilmenite, rutile, and sphene). The $\mathrm{La} / \mathrm{Ta}$ ratio varies significantly between $\mathrm{E}$-and $\mathrm{N}$-type MORB and active margin volcanics. The active margin volcanics are significantly depleted in $\mathrm{Ta}(\mathrm{La} / \mathrm{Ta}$ ratio $>30$ ) relative to the other more HYG elements (Sun et al., 1979; Wood, Joron, et al., 1979; Wood, Joron, and Treuil, 1979; Tarney et al., in press), which suggests that a minor Ti phase is involved at some stage in their

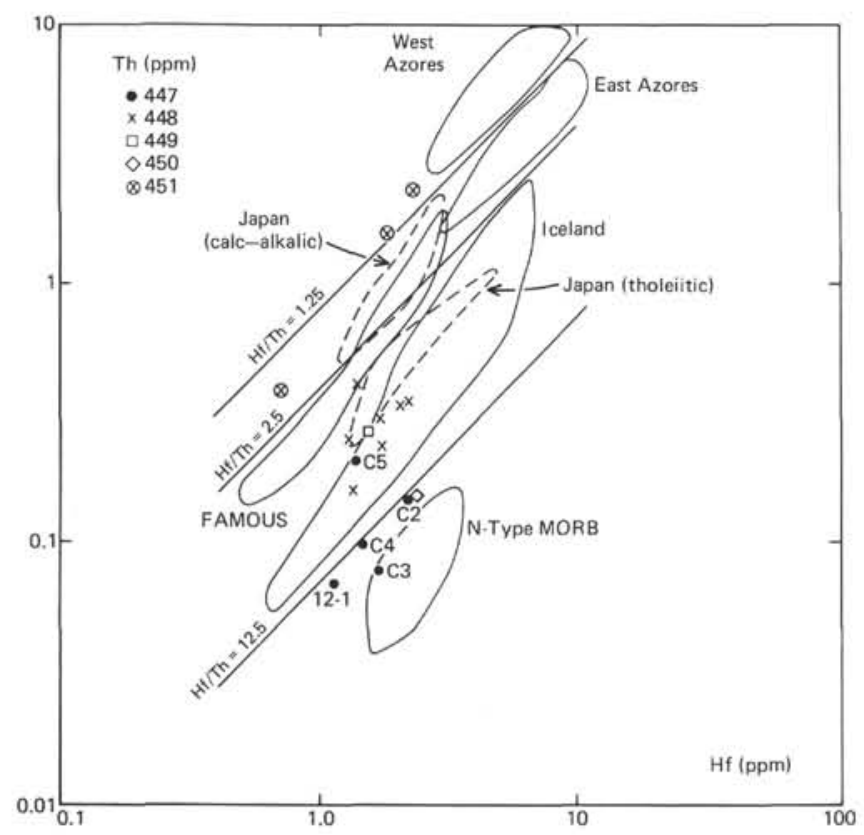

Figure 4. Log Th versus Log Hf for DSDP Leg 59 basement samples. The fields of lava series from other areas are from Wood, Varet, et al. (1979), Wood, Joron, et al., (1979), and Wood, Joron, and Treuil (1979). (Symbols same as for Fig 2.)

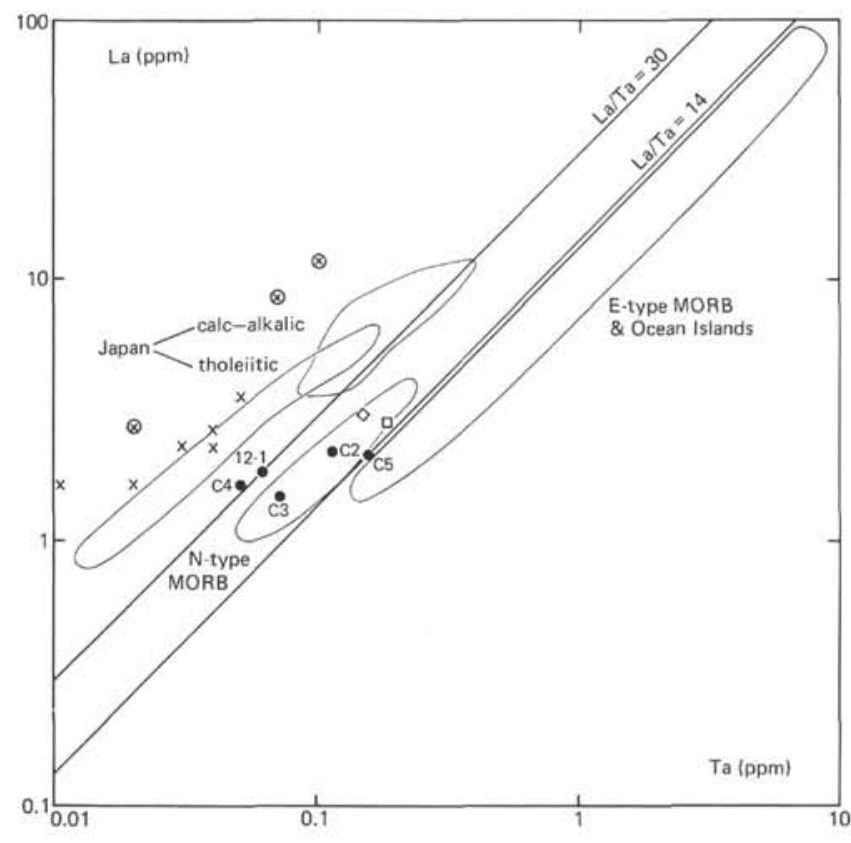

Figure 5. Log La versus Log Ta for DSDP Leg 59 basement samples. The fields of lava series from other areas are from Wood, Varet, et al. (1979), Wood, Joron, et al., (1979), and Wood, Joron, and Treuil (1979). (Symbols same as for Fig 2.)

genesis. Again the rocks from the basin sites plot close to the field of N-type MORB, and Site 448 rocks plot close to the Japanese arc tholeiite series. Site 451 rocks have significantly higher $\mathrm{La} / \mathrm{Ta}$ ratios than both the Site 448 rocks and the arc tholeiite and calc-alkalic series of Japan.

Figure 6 is a triangular diagram of Th-Hf/3-Ta in which Wood, Joron, and Treuil (1979) showed that volcanic rocks from different tectonic environments (including silicic differentiates) could be readily separated. The main distinction between oceanic and active margin volcanic series in this diagram is the relative depletion in $\mathrm{Ta}$ of the latter series. The rocks from the basin sites plot in the field of N-type MORB, although the samples from Chemical Unit 5, Sites 447 and 449, are more enriched in $\mathrm{Th}$ and $\mathrm{Ta}$ relative to $\mathrm{Hf}$, which will be discussed in more detail later in this chapter. The rocks from Sites 448 and 451 are clearly separated in Figure 6 and group with other island arc and calc-alkalic series, respectively.

The HYG element compositions of the basalts erupted in the West Philippine and Parece Vela basins are clearly identical to those erupted at normal mid-ocean ridges. Many of the basalts recovered at DSDP Sites 442, 443, and 444 (Shikoku Basin) also had HYG element compositions similar to basalts of the major ocean basin but included rock types similar to E-type MORB and ocean island basalts as well as N-type MORB (Marsh et al., in press; Wood et al., in press). It seems, therefore, that the basaltic crust of the West Pacific back-arc and interarc basins cannot be distinguished geochemically from oceanic Crustal Layer 2, particularly after alteration. This has important implications for the tectonic environment of formation of the crustal 


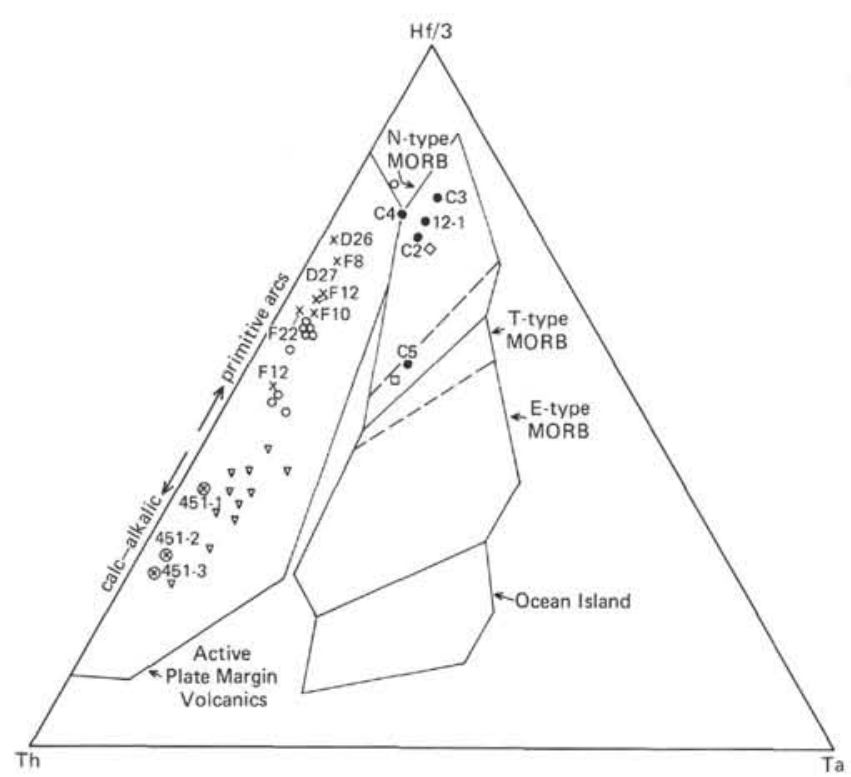

Figure 6. Th-Hf/3-Ta triangular diagram for DSDP Leg 59 basement samples and lavas from the calc-alkalic and arc tholeiite series of Japan (Wood et al., in press). The fields of the major terrestrial basalt types are slightly modified from Wood, Joron, and Treuil (1979). (Symbols same as for Fig. 2).

sections exposed in many ophiolite complexes. For example, the Late Cretaceous ophiolite complexes of the Middle East have crustal sections which include basalts of N-type MORB composition associated with active margin volcanics (e.g., Pearce, in press). A back-arc or interarc basin seems a reasonable tectonic environment for such a sequence of igneous rocks. It is perhaps more realistic that $\mathrm{N}$-type MORB could be preserved as an ophiolite by closure of a back-arc-interarc basin than by obduction of Crustal Layer 2 from a major ocean floor. Saunders, Tarney, et al. (in press) have also concluded that back-arc basin basalts and ocean floor basalts are equal contenders, on geochemical grounds, for ophiolite precursors.

\section{Detailed HYG Element Chemistry at the Basin Sites}

Mattey et al. (this volume) have described the petrographical and some of the geochemical effects of low-temperature sea water alteration, or halmyrolysis, to which all the basalts recovered from the basement sites have been subjected to a greater or lesser extent. The alteration of trace element concentrations in basaltic rocks during halmyrolysis has received much attention during recent years (e.g., Hart, 1971; Hellman and Henderson, 1977; Humphris and Thompson, 1978; Ludden and Thompson, 1979). These studies have shown that the elements $\mathrm{Cs}, \mathrm{Rb}, \mathrm{K}, \mathrm{U}$, and $\mathrm{Sr}$ are highly mobile during halmyrolysis and that $\mathrm{Ba}, \mathrm{Th}$, and the light rare earth elements (especially La) are also mobile, but to a lesser extent. These elements are often significantly enriched in the altered glassy margins of single pillows of basalt relative to the less altered massive pillow interiors. This is due to the crystallization of secondary minerals such as zeolites, calcite, and smectites, which can contain relatively high concentrations of the mobile HYG elements (e.g., Pritchard et al., 1979).

Mattey et al. (this volume) have compared microprobe analyses of fresh glass, glass showing various stages of devitrification, and whole rock XRF analysis from a single unit at Site 447 . The results show that halmyrolysis has generally resulted in a decrease in $\mathrm{SiO}_{2}, \mathrm{Al}_{2} \mathrm{O}_{3}, \mathrm{MgO}$, and $\mathrm{CaO}$, with increases in $\mathrm{K}_{2} \mathrm{O}$ (and possibly in $\mathrm{Na}_{2} \mathrm{O}$, but this could be due to volatile loss during the microprobe analyses) and presumably in $\mathrm{H}_{2} \mathrm{O}^{+}$and $\mathrm{Fe}_{2} \mathrm{O}_{3}$ (at the expense of $\mathrm{FeO}$ ). These changes are typical of those generally described for ocean floor basalts. Using immobile trace element data from the XRF whole rock analyses, Mattey et al. (this volume) have distinguished two fractionation trends in the basin site (one with $\mathrm{Ti} / \mathrm{Zr} \sim 125$ and $\mathrm{Zr} / \mathrm{Y} \sim 2$ and the other with $\mathrm{Ti} / \mathrm{Zr} \sim 90$ and $\mathrm{Zr} / \mathrm{Y} \sim 2.5$ ) which cannot be linked by realistic crystal fractionation processes. We have used these two coherent trends on biaxial plots of immobile HYG elements to look more closely at the effects of alteration on the mobile HYG elements.

Figure 7 shows a series of biaxial plots involving the immobile less HYG element Tb versus other HYG elements for the seven samples from the basin sites. In those plots which involve two immobile elements-i.e., Hf versus $\mathrm{Tb}, \mathrm{Zr}$ versus $\mathrm{Tb}$, and $\mathrm{P}_{2} \mathrm{O}_{5}$ versus $\mathrm{Tb}-$ the two linear fractionation trends mentioned in the foregoing can be clearly distinguished. However, when a mobile HYG element is involved, there is a considerably greater scatter. Nevertheless, the samples do vary systematically in most of the plots, and it is possible to distinguish between the samples in which the concentrations of the mobile HYG elements have been modified and those samples in which they have not. The samples from Chemical Units 2 and 3 generally lie along a straight line passing through the origin on plots of immobile versus slightly mobile elements (i.e., Ta versus $\mathrm{Tb}, \mathrm{Ce}$ versus $\mathrm{Tb}, \mathrm{La}$ versus $\mathrm{Tb}$ ), which we interpret as the primary characteristics of one fractionation trend. The sample from Chemical Unit 5 and from the basalt clast from the volcaniclastic breccia overlying the basement at Site 447 (Sample 447-12-1, 138-142 cm) generally plot away from this trend on plots of immobile versus slightly mobile elements; they are systematically enriched in the slightly mobile elements. We interpret the two latter samples as containing significantly modified concentrations of the slightly mobile elements. The same is true for the other fractionation trend samples from Chemical Unit 4, Sites 447 and 450 which lie along a straight line passing through the origin on the plots of immobile versus slightly mobile elements; the sample from Site 449 on the other hand is significantly enriched in the mobile elements. We interpret the element ratios defined by samples from Chemical Unit 4, Sites 447 and 450 , as primary.

Having obtained the primary HYG element ratios in this way, it is possible to estimate the primary concentration of a mobile element in an altered sample of a given fractionation trend and to calculate the magnitude by which it has been enriched during alteration of the sample. We have made this calculation for a number of 


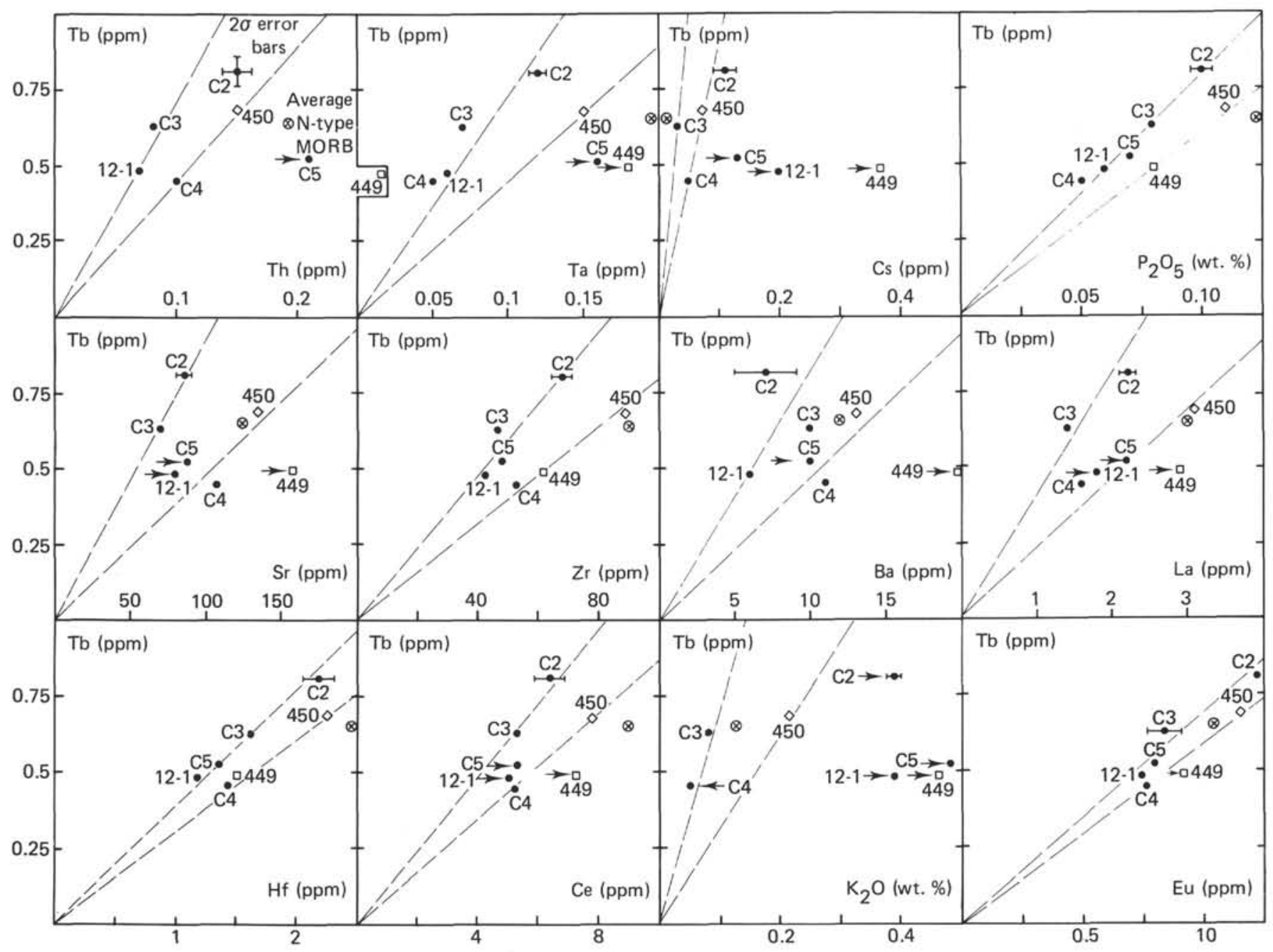

Figure 7. Biaxial plots of HYG elements versus Tb for DSDP Leg 59 samples from Sites 447, 449, and 450. (Symbols same as for Fig. 2 except that the cross in circle represents average N-type MORB [Wood, Varet, et al., 1979]. The bars represent \pm 2 -sigma analytical errors [Jaffrezic et al., in press; Tarney et al., 1979].)

HYG elements in the three altered samples (see Table 3). Two-sigma analytical error bars have been included in Figure 7 to indicate the precision of these calculations. The calculations have also been made for the more mobile elements ( $\mathrm{K}, \mathrm{Rb}$, and $\mathrm{Cs})$, but these are less accurate because the primary ratios of the elements with immobile elements are more difficult to define. The samples which showed no secondary modification of the less mobile elements contain in some cases modified concentrations of these more mobile elements. Furthermore, the analytical precision for $\mathrm{Ba}$ at concentrations of less than $20 \mathrm{ppm}$ is too poor to determine secondary enrichment factors accurately.

Nevertheless, the enrichment factors for the same element in the three samples are consistent and the results confirm that (1) $\mathrm{Cs}, \mathrm{Rb}$, and $\mathrm{K}$ are significantly more mobile than the other HYG elements; (2) Ba, Sr, and $\mathrm{La}$ have been enriched in the altered samples to a similar extent $(\sim \times 1.5$ to $\times 2)$; (3) Ce and Eu are very slightly enriched in the altered samples; (4) Th and Ta have been significantly enriched in the two samples that contain calcite veins (Chemical Unit 5, Sites 447 and 449) but
Table 3. Approximate secondary enrichment factors of HYG elements in intensely halmyrolyzed basin samples.

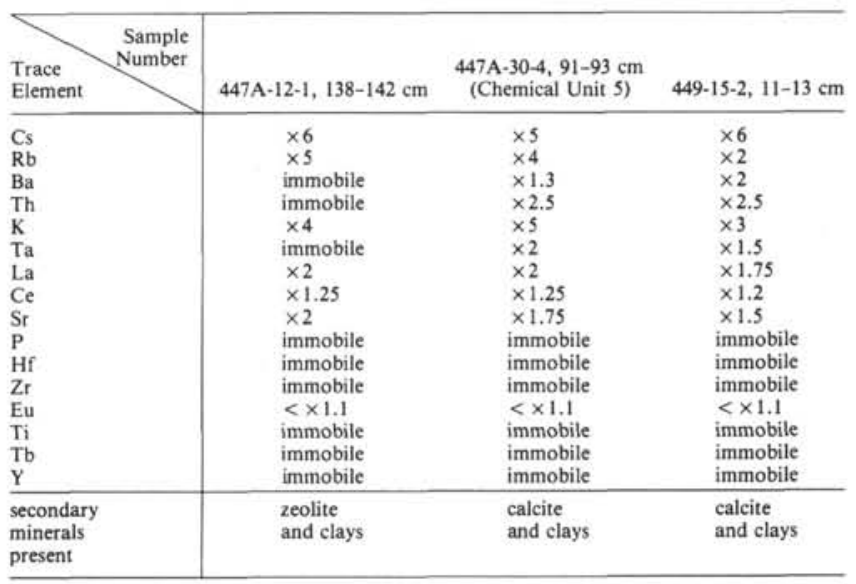

have not been modified in the sample containing zeolite (447-12-1, 138-144 cm). The primary concentrations of $\mathrm{Ta}$ and Th in N-type MORB are extremely low (less than 
$0.15 \mathrm{ppm}$ ), and ratios involving these elements are changed drastically by only very small increases $(\sim 0.1$ $\mathrm{ppm}$ ) in their concentrations. This is evident in Figure 4, where the samples from Chemical Unit 5, Sites 447 and 449 plot outside the field of N-type MORB, and in Figure 6, where they plot away from the rest of the samples from the basin sites (although still in the field of $\mathrm{N}$-type MORB). Th and Ta must therefore be considered as slightly mobile elements in N-type MORB subjected to halmyrolysis. We suspect that this mobility is directly related to the presence of calcite and the ability of $\mathrm{Ta}$ and $\mathrm{Th}$ to form soluble complexes with $\mathrm{CO}_{2}$-rich fluids. By avoiding samples which contain secondary calcite, the problem of the slight mobility of these elements could probably be overcome. It is somewhat encouraging that despite the intense alteration shown by the samples from Chemical Unit 5, Sites 447 and 449 and the slight mobility of Ta and Th, they still plot in the $\mathrm{N}$-type MORB field in Figure 6. However, it also stresses the need to analyze several samples showing various stages of secondary alteration, before identifying the tectonic environment in which a lava series was formed from the HYG element data.

In Figure 8, HYG element contents of the least altered samples (Chemical Unit 3, Sites 447 and 450) from the two fractionation trends shown by the basin sites have been normalized to estimated primordial mantle concentrations (Wood, Varet, et al., 1979). The elements in this diagram are arranged approximately from left to right in increasing order of bulk partition coefficient for anhydrous partial melting conditions $(>10 \%)$ of the upper mantle with only olivine, orthopyroxenes, and clinopyroxene \pm garnet in the residue. The composition of average N-type MORB (Sun et al., 1979; Wood, Varet, et al., 1979) has been plotted for comparison. Both the magma types from the basin sites plot close to the average N-type MORB composition with evidence to suggest that the $\mathrm{K}, \mathrm{Rb}$, and $\mathrm{Cs}$ concentra-

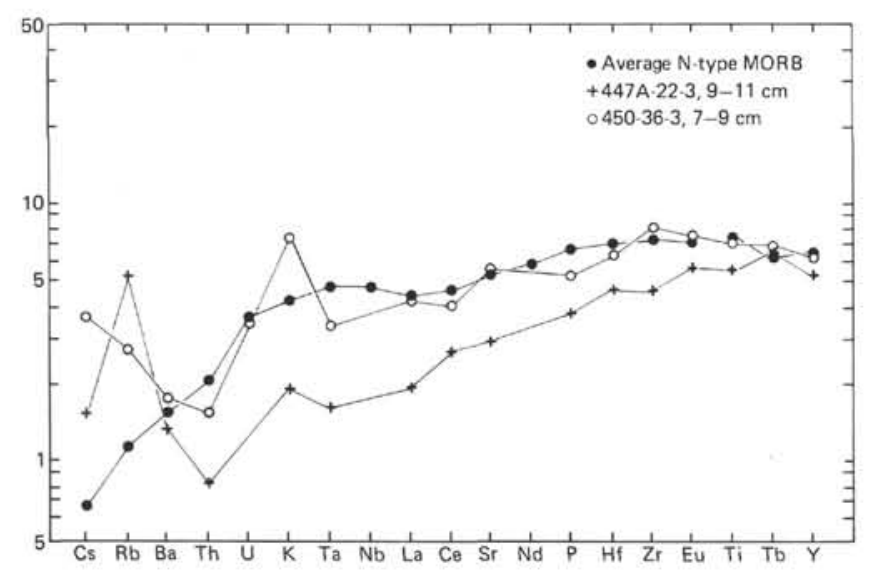

Figure 8. HYG element abundances of the two magma types recovered at the basin sites of DSDP Leg 59, normalized to the estimated primordial mantle abundances (Wood, Varet, et al., 1979). Average N-type MORB has been included for comparison. (A primordial mantle abundance of Ti-1200 ppm has been used instead of $1526 \mathrm{ppm}$ used by Wood, Varet, et al., [1979]. This gives more acceptable HYG element ratios of mantle materiale.g., $\mathrm{Ti} / 2 \times \sim 110$.) tions in even these least altered samples have been slightly modified. The magma type represented by the sample from Chemical Unit 3, Site 447 has slightly lower abundances of the more-HYG elements (those plotting toward the left in Figure 8) than the magma type represented by the sample from Hole 450 , and average $\mathrm{N}$-type MORB. If we assume that the generation of all MORB types involves significant degrees of partial melting $(>10 \%)$, the HYG element ratios in the basalts will be close to those of their respective mantle sources. When more than 10 per cent partial melting is involved, it is not easy to change HYG element ratios by fluctuations in the degree of partial melting of a single mantle source. The different HYG element ratios in the two magma types shown in Figure 8 would require large differences in the degrees of batch partial melting of a single mantle source. Also, the variation could be produced from a single mantle source by a continuous melting process (Langmuir et al. 1977; Wood, Joron, et al., 1979 ) in which the Hole 450 magma type is extracted from the source first (with some melt remaining in the source) and the more depleted Chemical Unit 3, Site 447 magma type subsequently extracted from the residue. Alternatively, the two magma types could be derived from different mantle sources; the latter originating in a mantle source which was slightly more depleted in the more HYG elements than the average N-type MORB source. It is necessary to obtain radiogenic isotope data before determining whether or not different mantle source compositions are involved.

\section{Detailed HYG Element Chemistry at the Ridge Sites}

The samples from Sites 448 and 451 have also suffered significant halmyrolysis, as is evident from the low major element totals in Table 2. This makes the data on the more mobile HYG elements suspect in terms of primary concentrations of the lavas. Figure 9 shows a series of biaxial plots of HYG elements in the samples from the ridge sites, together with data on the Japanese lava series in some cases. In each plot the more HYG element (according to the order in Figure 8) is plotted on the abscissa. All the samples from Site 448 conform to single straight line trends passing through the origin in plots of Th versus $\mathrm{Ta}$, Th versus $\mathrm{Ba}$, Th versus $\mathrm{Hf}, \mathrm{La}$ versus $\mathrm{Sr}, \mathrm{La}$ versus $\mathrm{Eu}$, and $\mathrm{La}$ versus $\mathrm{Ba}$, which suggests that the concentrations of these slightly mobile elements have not been significantly modified during alteration at this site.

Mattey et al. (this volume) have noted that the orthopyroxene basalt group at $\mathrm{Site} 448$ has lower $\mathrm{Ti} / \mathrm{Zr}$ ratios than the other basalt groups. This group has lower $\mathrm{Ti} /$ $\mathrm{Hf}(3300$ relative to 4800$)$ and slightly higher $\mathrm{Hf} / \mathrm{Tb}$, $\mathrm{Ce} / \mathrm{Tb}, \mathrm{La} / \mathrm{Tb}$, and $\mathrm{Zr} / \mathrm{Y}$ ratios. It is possible that this group represents slightly lower degrees of partial melting (of a similar source) than that involved in the genesis of the "olivine" and "clinopyroxene" basalt groups, which would produce a slight enrichment of the more HYG elements relative to the less HYG elements without changing the ratios of the more HYG elements (Th/ $\mathrm{Ta}, \mathrm{Ba} / \mathrm{La}$, etc.).

Although there are many similarities between the island arc tholeiites erupted on the Palau-Kyushu Ridge 


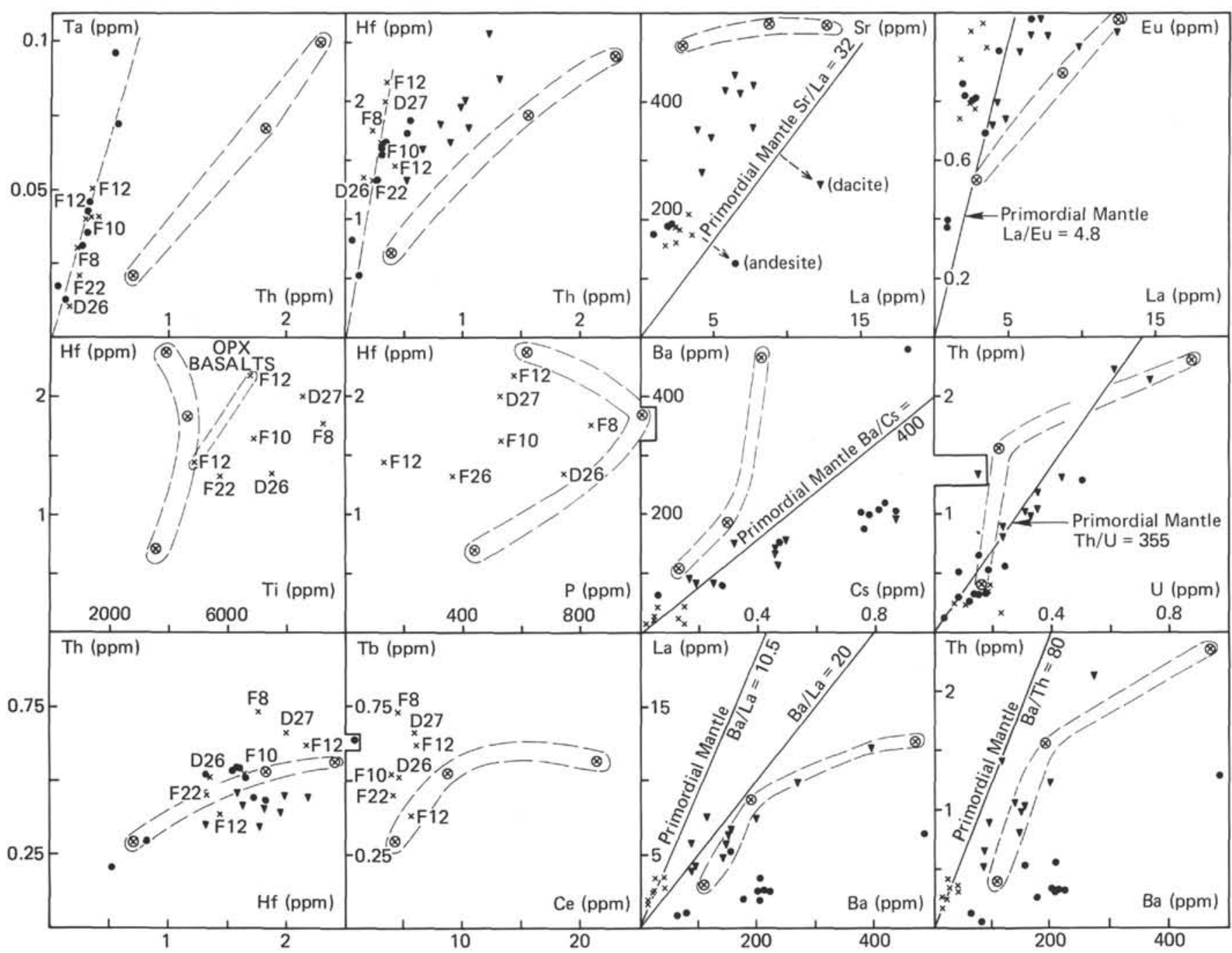

Figure 9. Biaxial plots of HYG elements for DSDP Leg 59 samples from Sites 448 and 451 together with samples from the calc-alkalic and arc-tholeiite series of Japan (Wood et al., in press). (Symbols same as for Fig 2.)

at Site 448 and the arc tholeiite series of Japan (cf. Figs. $4,5,6$, and 9), there are also significant differences. The main differences are the higher $\mathrm{Ba}$ and Lower $\mathrm{Na}_{2} \mathrm{O}$ content of the Japanese arc tholeiites (Figs. 3 and 9). The more evolved island arc thoeliites-calc-alkalic series erupted on the West Mariana Ridge at Site 451 show some similarities with the Japanese calc-alkalic series (cf. Figs. 4, 5, 6, and 9) but have higher $\mathrm{Sr}$ abundances, higher more/less HYG element ratios (e.g., $\mathrm{Th} / \mathrm{Hf}, \mathrm{Ba} / \mathrm{Tb}$, etc.), and higher $\mathrm{Th} / \mathrm{Ta}$ ratios (due to the very low Ta abundances). The more evolved andesites at Site 451 (e.g., the samples from Core 451-3, Table 2) and in the Japanese calc-alkalic series have higher $\mathrm{La} / \mathrm{Eu}$ ratios than the more basic rocks, which indicates the development of a negative Eu anomaly as the result of plagioclase fractionation.

The main HYG element features of the active margin volcanics described here are shown in Figure 10. In this diagram the HYG element abundances of primitive basalts from Sites 448 and 451 have been normalized to the estimated primordial mantle abundances, together with representative basalts from the two Japanese series.
There are three major features of active margin volcanics on this diagram: (1) the depletion of $\mathrm{Ta}$ (and $\mathrm{Nb}$ ) relative to the other more HYG elements; (2) the large fractionations among the more HYG elements (e.g., $\mathrm{Ba} / \mathrm{Th}$ ratio); (3) the calc-alkalic lavas are more enriched in the more HYG elements (but not necessarily the less HYG elements that the island arc tholeiites.

In the past five years, several trace elements and radiogenic isotope studies of the petrogenesis of continental margin and island arc magma series have suggested involvement of fluids derived from the dehydration of subducted oceanic crust (Best, 1975; Hawkesworth et al., 1978; Saunders, Tarney, and Weaver, in press). These hydrous fluids are thought to metasomatize the lithosphere overriding the subduction zone, which produces an enrichment of the mantle wedge above the subducted plate in the mobile elements concentrated in the hydrous secondary mineral phases of altered oceanic crust (e.g., Cs, $\mathrm{K}, \mathrm{Rb}, \mathrm{Pb}, \mathrm{Ba}, \mathrm{Th}, \mathrm{U}$, $\mathrm{La}$, and $\mathrm{Sr}$ ) as well as in radiogenic $\mathrm{Sr}$, since most of the water is ultimately of sea water origin. The introduction of a hydrous fluid would lower the solidus of the mantle 


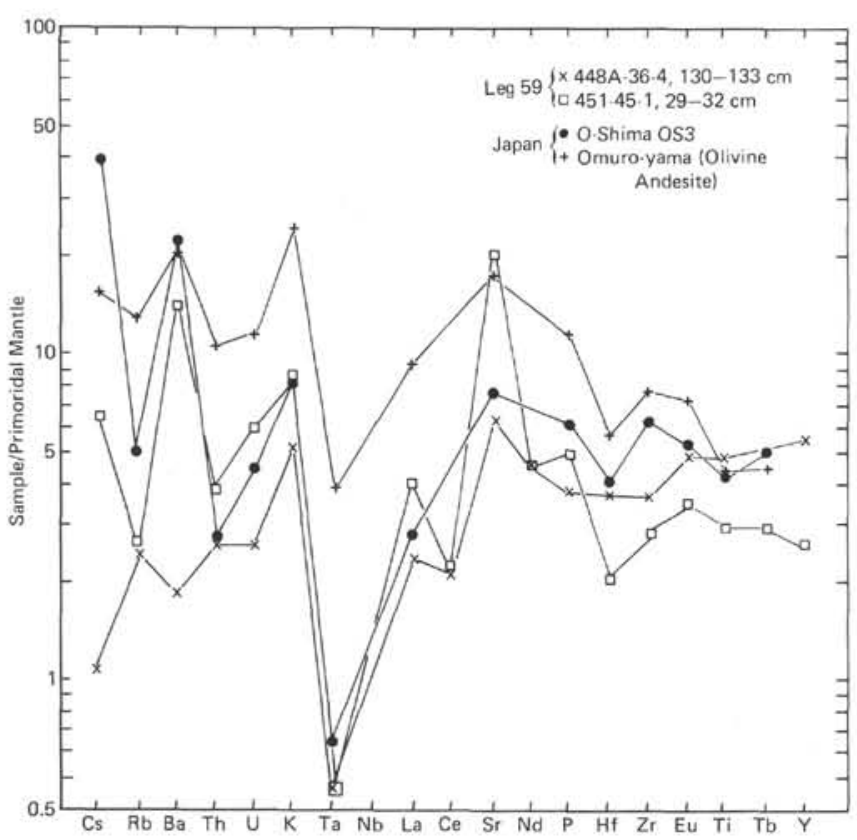

Figure 10. HYG element abundances of island arc and calc-alkali lavas normalized to the estimated primordial mantle abundances (Wood, Varet, et al., 1979).

wedge and induce partial melting under conditions of high $\mathrm{P}_{\mathrm{H}_{2} \mathrm{O}}$. The HYG element variations in active margin volcanics of the West Pacific are certainly consistent with this model.

In order to be able to explain the extremely low Ta and $\mathrm{Nb}$ abundances in active margin volcanics throughout the world (Joron and Treuil, 1978; Sun et al., 1979; Wood, Joron, et al., 1979; Saunders, Tarney, and Weaver, in press) it seems necessary to hypothesize that these elements are held in a mineral phase in the mantle during the partial melting (Wood, Varet, et al., 1979; Tarney et al., in press). $\mathrm{Ta}$ and $\mathrm{Nb}$ are strongly partitioned into titanium mineral phases-e.g., rutile and sphene. Recent experimental studies have shown that the stabilities of rutile and sphene are enhanced under hydrous conditions (Hellman and Green, 1979). If rutile or sphene survive the partial melting event and remain in the mantle residue, $\mathrm{Ti}$ cannot be considered as a hygromagmatophile element and its concentration in the melt phase will depend on the mass fraction of the $\mathrm{Ti}$ phase(s), the proportion it contributes to the melt, and the degree of partial melting. Several of the lavas plotted in Figure 10 have negative anomalies relative to the other less HYG elements which would be expected if a refractory $\mathrm{Ti}$ mantle phase were involved in their genesis. This might also explain why the differences between the "orthopyroxene" group and the other petrographic groups recovered at Site 448 are more pronounced on plots involving $\mathrm{Ti}$ if they are related to different degrees of partial melting.

\section{CONCLUSIONS}

1) The basalts erupted at Sites $447,449,450$ are geochemically indistinguishable from N-type MORB. This indicates that Crustal Layer 2 in the West Philippine and Parece Vela Basins cannot be chemically distinguished from Crustal Layer 2 of the major oceans.

2) In the intensely halmyrolized samples from Sites 447 and 449 , the elements $\mathrm{K}$. Rb, and Cs have been enriched by approximately a factor of $5 ; \mathrm{Sr}, \mathrm{La}$, and $\mathrm{Ba}$ have been enriched by approximately a factor of 2 ; and $\mathrm{Ce}$ has been enriched by a factor of 1.25 . The elements $\mathrm{P}, \mathrm{Hf}, \mathrm{Zr}, \mathrm{Ti}, \mathrm{Tb}$, and $\mathrm{Y}$ are immobile. In two samples subjected to alteration with calcite Th and Ta have been enriched by a factor of 2.5 and about 2, respectively, but are immobile in samples not containing calcite. Even the altered samples plot in the field of N-type MORB in the Th-Hf/3-Ta triangular discrimination diagram.

3) The basalts recovered from Site 448 on the PalauKyushu Ridge are primitive island arc tholeiites, with compositions similar to arc tholeiites from Japan, though with systematically lower $\mathrm{Ba}$ and higher $\mathrm{Na}_{2} \mathrm{O}$.

4) The basalts recovered from Site 451 on the West Mariana Ridge are more evolved island arc tholeiites with strong calc-alkalic tendencies and are similar to the calc-alkalic series from Japan, but with higher $\mathrm{Sr}$ and lower abundances of $\mathrm{Ta}$ and the less HYG elements.

5) The enrichment of the alkali elements $\mathrm{Sr}, \mathrm{La}, \mathrm{Th}$, and $U$ in the active margin volcanics of the West Pacific is consistent with a petrogenetic model involving metosomatism of the mantle wedge above a subducted zone (with hydrous fluids derived from the subducted crust) prior to or at the time of partial melting in the mantle wedge. The depletion of $\mathrm{Ta}$ and $\mathrm{Nb}$ in these volcanics can be explained by the presence of a refractory $\mathrm{Ti}$ phase in the mantle residue.

\section{ACKNOWLEDGMENTS}

This study was supported by the Natural Environment Research Council (U.K.) and the Centre National de la Recherche Scientifique (France).

\section{REFERENCES}

Best, M. G., 1975. Migration of hydrous fluids in the upper mantle and potassium variation in calc-alkalic rocks. Geology, 3:429432.

Chayla, B., Jaffrezic, H., and Joron, J. L., 1973. Analyse par activation dans les mentions épithermiques. Application à la détermination d'éléments en trace dans les roches. Comptes Rend. Acad. Sci. Paris, 227:273-275.

Hart, S. R., 1971. K, Rb, Cs, Sr and Ba contents and $\mathrm{Sr}$ isotope ratios of ocean floor basalts. Philos. Trans. Roy. Soc. London Ser. A, 268:573-588.

Hawkesworth, C. J., O'Nions, R. K., Pankhurst, R. J., et al., 1978. A geochemical study of island arc and back-arc tholeiites from the Scotia Sea. Earth Planet. Sci. Lett., 36:253-262.

Hellman, P. L., and Green, T. H., 1979. The role of sphene as an accessory phase in the high pressure partial melting of hydrous mafic compositions. Earth Planet. Sci. Lett., 42:191-201.

Hellman, P. L., and Henderson, P., 1977. Are rare earth elements mobile during spilitisation? Nature, 267:38-40.

Humphris, S. E., and Thompson, G. 1978. Trace element mobility during hydrothermal alteration of oceanic basalts. Geochim. Cosmochim. Acta, 42:127-136.

Jaffrezic, H., Joron, J. L., Treuil, M., et al., in press. A study of the precision obtained by neutron activation analysis using international standard rocks GS-N and BCR-1 as examples. A discussion of a geochemical model accounting for the estimated errors. $J$. Radioanalyt. Chem.

Joron, J. L., Bougault, H., Wood, D. A., et al., 1978. Application de la géochimie des éléments en trace a l'étude des propriétés et des 
processus de genèse de la crôte oceanique et du manteau superieur. Bull. Geol. Soc. France, 20:521-531.

Joron, J. L., and Treuil, M., 1978. Utilisation des propriétés des éléments fortement hygromagmatophiles pour l'étude de la composition chimique et de l'hétérogenéité du manteau. Bull. Geol. Soc. France, 19, 1197-1205.

Kuno, H., 1968. Differentiation of basaltic magmas. In Hess, H. H., and Poldervaart, A. (Eds.), Basalts (Vol. 2): New York (Wiley), 623-688.

Langmuir, C. H., Bender, J. F., Bence, A. E., et al., 1977. Petrogenesis of basalts from the FAMOUS area: Mid-Atlantic Ridge. Earth Planet. Sci. Lett., 36:133-156.

Ludden, J. N., and Thompson, G., 1979. An evolution of the behaviour of the rare earth elements during the weathering of sea-floor basalt. Earth Planet. Sci. Lett., 43:85-92.

Marsh, N. G., Saunders, A. D., and Tarney, J., in press. Geochemistry of basalts from the Shikoku and Daito Basins, DSDP Leg 58. In Klein, G. DeV., Kobayashi, K., et al., Init. Repts. DSDP, 58: Washington (U.S. Govt. Printing Office).

Pearce, J. A., in press. Geochemical evidence for the genesis and eruptive setting of lavas from Tethyan Ophiolites. Proceedings of the Symposium on Ophiolite Problems. Geol. Survey: Cyprus.

Pritchard, R. G., Cann, J. R., and Wood, D. A., 1979. Low temperature alteration of oceanic basalts, DSDP Leg 49. In Luyendyk, B. P., Cann, J. R., et al., Init. Repts. DSDP, 49: Washington (U.S. Govt. Printing Office), 709-714.

Saunders, A. D., Tarney, J., Marsh, N. G., et al., in press. Ophiolites as oceanic crust or margin basin crust: A geochemical approach. Proceedings of the Symposium on Ophiolite Problems. Geol. Survey: Cyprus.

Saunders, A. D., Tarney, J., and Weaver, S. D., in press. Transverse geochemical variations across the Antarctic Peninsula: Implications for the genesis of calc-alkalic magmas. Earth Planet. Sci. Lett.
Sun, S. S., Nesbitt, R. W., and Sharaskin, A. Y., 1979. Geochemical characteristics of mid-ocean ridge basalts. Earth Planet. Sci. Lett., 44:119-138.

Tarney, J., Saunders, A. D., Weaver, S. D., et al., 1979. Minor element geochemistry of basalts from Leg 49, North Atlantic Ocean. In Luyendyk, B. P., Cann, J. R., et al., Init. Repts. DSDP, 49: Washington (U.S. Govt. Printing Office), 657-691.

Tarney, J., Wood, D. A., Saunders, A. D., et al., in press. Nature of mantle heterogeneity in the North Atlantic: Evidence from deep sea drilling. Philos. Trans. Roy. Soc. London Ser. A.

Wood, D. A., 1979a. A variably veined sub-oceanic upper mantle: Genetic significance for mid-ocean ridge basalts from geochemical evidence. Geology, 7:499-503.

1979b. Dynamic partial melting and its application to the petrogenesis of basalt lava series from Iceland, the Faeroe Islands, the Isle of Skye (Scotland) and the Troodos Massif (Cyprus). Geochim Cosmochim. Acta, 43:1031-1046.

Wood, D. A., Joron, J. L., Marsh., N. G., et al., in press. Major- and trace-element variations in basalts from the North Philippine Sea drilled during Deep Sea Drilling Project Leg 58: A comparative study of back-arc basin basalts with lava series from Japan and mid-ocean ridges. In Klein, G. deV., Kobayashi, K., et al. Init. Repts. DSDP, 58: Washington (U.S. Govt. Printing Office).

Wood, D. A., Joron, J. L., Treuil, M., 1979. A re-appraisal of the use of trace elements to classify' and discriminate between magma series in different tectonic settings. Earth Planet. Sci. Lett., 45: 326-336.

Wood, D. A., Joron, J. L., Treuil, M., et al., 1979. Elemental and Sr isotope variations in basic lavas from Iceland and the surrounding Ocean floor: The nature of the mantle source in homogeneities. Contrib. Mineral. Petrol., 70:319-339.

Wood, D. A., Varet, J., Bougault, H., et al., 1979. The petrology, geochemistry and mineralogy of North Atlantic basalts: A discussion based on IPOD Leg 49. In Luyendyk, B. P., Cann, J. R., et al., Init. Repts. DSDP, 49: Washington (U.S. Govt. Printing Office), 695-755. 